Wilfrid Laurier University

Scholars Commons @ Laurier

$5-1-1993$

\title{
Cultural Absolutism and the Nostalgia for Community
}

Rhoda E. Howard-Hassmann

Wilfrid Laurier University, hassmann@wlu.ca

Follow this and additional works at: https://scholars.wlu.ca/poli_faculty

\section{Recommended Citation}

Howard-Hassmann, Rhoda E., "Cultural Absolutism and the Nostalgia for Community" (1993). Political Science Faculty Publications. 23.

https://scholars.wlu.ca/poli_faculty/23

This Article is brought to you for free and open access by the Political Science at Scholars Commons @ Laurier. It has been accepted for inclusion in Political Science Faculty Publications by an authorized administrator of Scholars Commons@ Laurier. For more information, please contact scholarscommons@wlu.ca. 


\title{
Cultural Absolutism and the Nostalgia for Community
}

\author{
Rhoda E. Howard
}

\section{CULTURAL RELATIVISM AS CULTURAL ABSOLUTISM}

In recent years the liberal approach to human rights has undergone a twofold assault, from both the right and the left. From the right, liberal human rights are attacked by a new version of communalism that promotes the integrative protection of the human being in the community as against the socially alienating effects of individual human rights. From the left, liberalism is attacked by a collectivist approach to human rights based on notions of ascriptively-based privileges or disadvantages in society. In the international debates on the relevance of human rights, right traditionalism has combined with left collectivism; allegedly communitarian third world societies are considered victims of an imperialist liberal agenda of human rights emanating from the Western-dominated United Nations. The concept of cultural relativism is used by both traditionalists and communitarians as a defense of their "way of life" against the individualism and alienation that liberal human rights are thought to imply. But the relativism that is implicit in such arguments is actually a concept of cultural absolutism.

Cultural absolutism is a philosophical position that declares a society's culture to be of supreme ethical value. It advocates ethnocentric adherence to one's own cultural norms as an ethically correct attitude for everyone except loosely-defined "Westerners." It thus posits particularist cultures as of more ethical value than any universal principle of justice. In the left-right/ North-South debate that permeates today's ideological exchanges, cultural absolutists specifically argue that culture is of more value than the internationally-accepted (but Western in origin) principle of human rights.

Human rights are considered in international law to be rights held equally by every individual by virtue of his or her humanity, and for no other reason. Human rights are non-derogable claims against both society and the state that are not contingent upon performance of specific duties. This article will 
assume that defense of universal human rights is a worthwhile ethical position in the modern world. In complex state societies, human rights defend individuals against political abuse. Most individuals would prefer for themselves the protections that human rights offer, although they might not agree that others should have the same protections.

A system of justice based on human rights is one particular system. There can be other systems of justice not based on human rights. In general, social justice can be defined as the means by which all members of a society are treated in a fashion considered respectful of their culturally defined social station. Justice consists of rules of appropriate social behavior and rules of fairness that might not contain the basic principles of human rights, namely that rights are individual and that everyone, regardless of status, is equally endowed with them. But some cultural relativists argue that all culturallybound systems of social justice are human rights systems no matter what their substantive content or overarching principles. In making this claim, relativists undermine the actual meaning of human rights and leave the door open to severe abuses of individuals in the name of the rights of the collectivity or the community.'

Because "human rights" is an ideologically and politically loaded phrase that has great moral cachet in contemporary world political debate, most political elites find it in their interests to pretend to believe in human rights. Spokespersons for a large number of societies whose systems of social justice are quite explicitly not based on human rights-that is, on the individual, autonomous capacity to make rights claims against society and the statetherefore contend that they do indeed have human rights: socialist, Muslim, Hindu, or other varieties thereof. They claim that sensitivity to the relativity of culture will result in acknowledgement that each culture has its own indigenous concept of human rights.

Cultural relativism is a method "whereby social and cultural phenomena are perceived and described in terms of scientific detachment or, ideally, from the perspective of participants in or adherents of a given culture." ${ }^{2}$ This method of analysis evolved in the early twentieth century to counteract Westerners' nineteenth-century belief that their own white, Christian society was morally superior to all others. During the colonial period, belief in Western moral superiority justified anthropological study of "primitive" or "native" cultures, and anthropologists who clearly held to visions of white superiority abetted Western imperial conquest. Given the many attempts by Western powers to destroy indigenous societies, cultural relativism was and

1. This discussion of social justice is from my "Dignity, Community and Human Rights," in Human Rights in Cross-Cultural Perspective: A Quest for Consensus, ed. Abdullahi A. AnNa'im (Philadelphia: University of Pennsylvania Press, 1992), 81-102.

2. David Bidney, "Cultural Relativism," in International Encyclopedia of the Social Sciences, ed. David L. Sills (New York: Macmillan, 1968), 3:543. 
remains a valuable defense of indigenous societies against attack and destruction by colonialists, missionaries, and others.

Cultural relativism is not only a method, it is also an ethical stance. Relativism assumes that there is no one culture whose customs and beliefs dominate all others in a moral sense. But this relativism is now sometimes taken to such an extreme that any practice of an indigenous society can be theoretically defended merely on the grounds that it is a local "custom." And outsiders' discussions of local violations of human rights are criticized as unwarranted ideological interference. When taken to this absolutist extreme, the term "cultural relativism" implies that all cultures are morally or ethically equal, that there should be no judgements made of their comparative intrinsic worth. Jack Donnelly refers to this ethical position as "radical" cultural relativism, which holds that "culture is the sole source of the validity of a moral right or rule." ${ }^{13}$ Radical cultural relativism can be renamed cultural absolutism.

The absolutist school claims, in effect, that human rights are not relevant to cultures that do not share "Western" customs, norms, beliefs, and values. Human rights are a notion culturally specific to the Western world. Different societies have different cultures that are not comparable. All cultures, moreover, are morally equal. Since cultures are not comparable, human rights are not and should not be universal, and no Westerner has the right to discuss ways that other cultures could or should reorient their ethical systems. Human rights, in a now famous phrase, are a "Western construct with limited applicability." ${ }^{\prime 4}$

The absolutist argument against universal human rights has three separate aspects. First, the absolutist argument confuses the principle of universality with practice, which is clearly not universal. Universalism is untenable because in practice, human rights are not protected worldwide. For example, Pollis and Schwab, two leading relativists in the international human rights debate, noted in 1980 that human rights took second place to states' rights in many African countries and in socialist societies; they therefore concluded that what was not practiced was not relevant in principle. ${ }^{5}$ This position confuses the immediate existence of human rights with their possible legal and practical relevance. A medical analogy illustrates the illogical character of this argument; one would not argue that lack of access to health care in third world or socialist societies means health care is irrelevant. And in fact, the argument against universalism usually is made

3. Jack Donnelly, Universal Human Rights in Theory and Practice (Ithaca: Cornell University Press, 1989), 109.

4. Adamantia Pollis and Peter Schwab, "Human Rights: A Western Construct with Limited Applicability," in Human Rights: Cultural and Ideological Perspectives, eds. Adamantia Pollis and Peter Schwab (New York: Praeger, 1980), 1-18.

5. Ibid., 11. 
with reference to civil and political rights, not to economic rights such as medical care. The fallacy of confusing practice and principle pervades a recent volume presenting a political economy critique of human rights in Africa. "IF]or countries that have known no peace, stability, or progress since their contact with the forces of Western imperialism, civil and political rights have no meaning." ${ }^{6}$

Apparently, something that one lacks is not meaningful; one is not capable of speculating on what the quality of one's life would be if one had that which one lacked. But social movements for political change arise precisely because people do envisage a life in which more of their rights are protected. International human rights are a standard to which it would not be necessary to devote so much effort if they were already firmly protected everywhere. Those who advocate human rights as a universal principle do so precisely because rights are not universally respected. To claim that that which is not present is irrelevant assumes that those who are denied rights do not have the intellectual capacity to articulate their suffering and to grasp the fundamental principles of justice that human rights imply. Such a claim reinforces the stereotype of the "native" as a non-thinking, primitive being whose pain is part of the one-ness of his existence.?

The second absolutist argument refers not to practice but to principle. Universal human rights are untenable because in principle, human rights are not a universal cultural ideal. This argument usually applies to the content of particular rights such as equality for women. "[T]he belief that women are entitled to equal status as citizens . . . is not universally accepted in African, Islamic or Western societies."

But cultural absolutists simultaneously argue that human rights are a universal ideal. The concept of rights is universal, but the content (what, substantively, are or ought to be rights) varies among different societies. All cultures, absolutists claim, have some ideals of human rights, although these ideals may seem strange to Western eyes since they do not include norms such as equality that are basic to the United Nations' human rights framework. Thus, for example, the Hindu caste system is proposed as a system of human rights. "The fact that certain groups [in India], the lower castes, for example, the untouchables, are denied human rights in no way proves

6. Julius $O$. Thonvbere, "Underdevelopment and Human Rights Violations in Africa," in Emerging Human Rights: the African Political Economy Context, eds. George W. Shepherd, Jr. and Mark O. C. Anikpo (New York: Greenwood Press, 1990), 57.

7. Thus Isak Dinesen in Out of Africa (New York: Vintage Books, 1972 [1st ed. 1937]), 27883 , who without any self-consciousness whatsoever, romanticized the stoicism of a "native" of her acquaintance as he awaited the death brought on by a beating by his colonial master. Ngugi wa Thiong'o, the Kenyan novelist, discusses Dinesen's perceptions of natives in his Detained: a Writer's Prison Diary (London: Heinemann, 1981), 35-36.

8. Alison Dundes Renteln, "The Unanswered Challenge of Relativism and the Consequences for Human Rights," Human Rights Quarterly 7 (November 1985): 534. 
that the society lacks a concept of human rights." ${ }^{\prime \prime}$ This approach argues that all systems of social justice are systems of human rights. It is more important to give all systems of justice the ideologically pure label of human rights than to differentiate among such systems and discover which ones allocate substantive and equal rights and dignity to all individuals purely on the basis of their humanity, and which allocate only privileges and duties contingent on unequal social status.

The third absolutist argument is that universalism is untenable because (it is argued implicitly) indigenous cultures supersede human rights as a social good. "[C]ultural relativism [absolutism] may be defined as the position according to which local cultural traditions (including religious, political, and legal practices) properly determine the existence and scope of civil and political rights enjoyed by individuals in a given society." ${ }^{10}$ This is the key to the absolutist perspective. For absolutists, culture is the supreme ethical value, more important than any other. Human rights, in particular, should not be promoted if their implementation might result in a change in a particular culture.

But cultural absolutists do not fully reject universalist ethics as they claim to do. Cultural absolutists actually posit one universal ethical law, that

a) there are no universal moral principles;

b) one ought to act in accordance with the principles of one's own group; and

c) (b) is a universal moral principle. ${ }^{11}$

This law carries more moral weight for absolutists than the law of universal human rights, although it is itself a principle that cannot be located in all cultural systems. If one were to look for it, one would probably find rather that most cultures believe that their own moral principles ought to be universal.

[The individual cannot but be convinced that his own way of life is the most desirable one.... [D]espite changes originating from within and without his culture that he recognizes as worthy of adoption, it becomes equally patent to him that, in the main, other ways than his own ... are less desirable ....'

Thus the logical position that most people embedded in their own cultures will take is:

9. Ibid., 527.

10. Fernando R. Teson, "International Human Rights and Cultural Relativism," Virginia Journal of International Law, 25 (Summer 1985): 870.

11. Ibid., 888.

12. This is taken from the classic "Statement on Human Rights," unsigned but known to be written by Melville Herskovitz, American Anthropologist, new series, 49 (Oct.-Dec. 1947): 540. 
a) there are universal moral principles;

b) our own culture embodies these principles; and

c) everyone else ought to follow our principles even if this means abandoning his or her own culture.

Thus, circumcised fight uncircumcised, Christians and Muslims slaughter each other, vegetarians despise meat-eaters, and so on all over the world. It is precisely because of each society's tendency to think its own culture the best that we need a basis for judging social justice that is not culturebound.

The third absolutist argument, that indigenous cultures supersede human rights as a moral good, is the major theme of a book by Alison Dundes Renteln, the most recent exemplar of the cultural absolutist school of human rights. ${ }^{13}$ Renteln believes that the 1948 Universal Declaration of Human Rights was so heavily influenced by Western thought as to have no pertinence to non-Western societies; indeed, human rights are an ethnocentric value of Westerners. But simultaneously, she argues that in fact all societies do have their own human rights standards. In order to avoid ethnocentrism, she proposes that the only universal human rights standards be those empirically shown to be universal cultural ideals. Thus in practice Renteln does not completely reject universality. But she argues for additive, rather than ethical, universality: only a principle shown to be universal once we have looked for its presence or absence in all cultures is legitimate. The only principle that is universal on an ethical basis alone is that all societies ought to (ethnocentrically) adhere to their own culture.

Renteln believes that one can discover human rights, or their "homeomorphic equivalent" ${ }^{\prime 14}$ in all societies. As an example of how to identify her universal homeomorphic equivalents, she uses the international legal prohibition of genocide. She reviews anthropological studies of retribution, feuds, and vendettas which, she argues, show that there are cultural rules of vengeance in most societies that limit the number of deaths permitted. This, Renteln contends, is evidence of a universal standard against genocide that is culturally entrenched, not dependent on a Western ethical norm.

One can certainly accept Renteln's view that international human rights standards have a better chance of being put into practice if they also reflect cultural ideals. This is a position that the Muslim legal scholar Abdullahi Ahmed An-Na'im also espouses, in his search for Qur'anic justifications for equal rights for women, better treatment for religious minorities, and the end of the notion of jihad (holy war) as a basis for relations between Muslim

13. Alison Dundes Renteln, International Human Rights: Universalism Versus Relativism (Newbury Park, CA: Sage, 1990).

14. Ibid., 11. 
and non-Muslim states. ${ }^{15}$ But An-Na'im has been unable to find any internal Muslim precept that could be used to abolish the hudud punishments (amputation of limbs for theft) presently used in his native Sudan. ${ }^{16}$ This illustrates the difficulty of limiting ethical principles to those extant in particular cultural traditions, rather than acknowledging the legitimacy of abstract, philosophical consideration of ethical questions that is transcultural and denies the preemptive claim of cultures to a superior moral status.

In the world of cultural absolutism, ethical debate in universalist terms is simply not countenanced: particularist cultures are all-encompassing. But if culture is as all-encompassing as absolutists contend, it ought to be impossible in practice for philosophers, lawyers, human rights activists, or indeed ordinary citizens within a society to transcend culture-boundedness or to make ethical judgments of their own customs. All we can do to promote universal human rights is to wait until cultures evolve internally, but not in reaction to the stimulus of thoughtful human agency. This flies in the face of all empirical evidence. Despite the cultural absolutists' belief that abstract, transcultural ethical discussions are impossible, all sorts of people insist on holding them. Cultural absolutists thereupon maintain that these discussions may not be impossible, but they are unethical.

The Argentinean legal scholar Fernando R. Teson refers to the idealization of culture as elitist. He disputes the position that

. . countries that do not spring from a Western tradition may somehow be excused from complying with the international law of human rights. This elitist theory ... holds that human rights are good for the West, but not for much of the non-Western world. [R]elativist [absolutist] scholars ... wish to respect the autonomy of individual cultures. The result is a vague warning against "ethnocentrism" and well-intentioned proposals that are deferential to tyrannical governments and insufficiently concerned with human suffering. Because the consequence ... is that certain national or ethnic groups are somehow less entitled than others to the enjoyment of human rights, the theory is fundamentally immoral and replete with racist overtones."

Moral discourse, contends Teson, is universalizable. ${ }^{18}$ Thus it is perfectly legitimate for a Westerner to advocate universal human rights and to discuss the possibilities for their protection worldwide. Human rights are about protection of people's lives, safety, and individual freedom. They are a

15. Abdullahi Ahmed An-Na'im, Toward an Islamic Reformation: Civil Liberties, Human Rights, and International Law (Syracuse: Syracuse University Press, 1990).

16. Abdullahi Ahmed An-Na'im, "Toward a Cross-Cultural Approach to Defining International Standards of Human Rights: the Meaning of Cruel, Inhuman, or Degrading Treatment or Punishment," in Human Rights in Cross-Cultural Perspectives: A Quest for Consensus, note 1 above, 36 .

17. Teson, note 10 above, 895 .

18. Ibid., 889. 
supreme universal value in the sense that most people, deprived of these protections, want to have them, regardless of the culture in which they live. "Unauthentic" third world thinkers who favor human rights should not be rejected as betrayers of traditional cultures. Without such "betrayal," their cultures may very well stultify in the hands of self-serving elites.

\section{AN ABSOLUTIST DEFENSE OF A WHITE CANADA}

The absolutist position maintains that human rights are a Western cultural imposition on the rest of the world. It posits a very crude understanding of what the "West" is and how culture and politics interact. It ignores the diversity of cultures within the West. It also confuses political philosophies with cultures, attributing one such philosophy, namely liberalism, to all Western societies and ignoring other Western philosophies such as communism, corporatism, and fascism that do not hold to human rights norms.

Culturalist arguments are usually made with respect to the former colonized nations of the world or to indigenous peoples in settler states. But to be consistent, culturalist arguments should also apply to large-scale, Western societies. All large-scale political units have internal cultures, although they may not be identified as such because internal conflicts and expressions of non-integrative particularist interests will be more obvious than in the small-scale, homogeneous communities that anthropologists have traditionally studied. If indigenous and third world cultures are to be allowed the complete play of their values, beliefs, norms, and customs regardless of whether or not they conform to international human rights standards, then the cultures of other societies should have the same privileges. Any society should be permitted to retain its culture regardless of human rights considerations. If absolutists reject this position then they are arguing that some cultures (in practice, indigenous third world ones) are more "absolute" than others; that some are absolutely worth preserving, whereas others can be changed or destroyed. They thus reverse the cultural imperialism that they contend characterizes the universal human rights documents, giving greater weight to non-Western than to Western ethical beliefs.

If culture is a preemptive social good, with a higher moral standing than human rights, and if the only universal rule is that one ought to act in accordance with the principles of one's own group, then no cultural absolutist should find shocking the following argument about the nature of Canadian society.

Canada is a white Protestant society of British origin (except Quebec). Its values are honesty, hard work, attachment to family, social rectitude, and loyalty to the monarchy. Canadians are a quiet people, not given to displays of emotion or unbridled festivities. They are sexually restrained. 
Immigration to Canada must be very carefully controlled so that these values are not destroyed. People of Slavic or Latin origin have different social values than Northern Europeans - they tend to be noisier and less restrained, and have larger families. Jews are known to be merchants of questionable ethics; they are not capable of real attachment to the land or to the monarchy. The Chinese and Japanese are good workers but their culture is incompatible with ours because they are neither British nor white, so they must not be allowed to stay in Canada except on short-term work permits. No decent Canadian would want to live in the same community as blacks, who are noisy, smelly, sexually unrestrained and criminal, so they should not be allowed to enter Canada either. ${ }^{19}$

The above is a fair representation of dominant social attitudes in Canada until well into the 1950s. Many Canadians would contend that it is still an accurate representation of their society's cultural values today, and some would be willing to stop all further immigration of non-Europeans, indeed to send not only immigrants but also some native-born Canadians (particularly blacks) "home."

Preservation of white and Christian Canadian culture keeps the community close, and promotes the security of its members by not exposing them to different people with different customs. As Michael Walzer has stated:

[T] he right to choose an admissions policy [to one's country] ... is not merely a matter of acting in the world, exercising sovereignty, and pursuing national interests. At stake here is the shape of the community that acts in the world, exercises sovereignty, and so on. Admission and exclusion are at the core of communal independence. They suggest the deepest meaning of self-determination. Without them, there could not be communities of character, historically stable, ongoing associations of men and women with some special commitment to one another and some special sense of their common life. ${ }^{20}$

Communities of character with a special sense of common life are a morally valuable social good. To belong to a community that shares your values, in which you feel at ease and in which everyday social intercourse is based on commonly acknowledged rules and customs is to find social life pleasant, rather than confusing or shocking. Canada is a typical Western society in so far as its immigration is carefully controlled to maintain its community of character in ways that, until very recently, violated international human rights norms.

Canada has a long history of exclusion of non-white, non-Christian immigrants. Immigration policy has favored people of British or Northern

19. This is not a quotation but my own summary of a position with which, obviously, I disagree.

20. Michael Walzer, Spheres of Justice: A Defense of Pluralism and Equality (New York: Basic Books, 1983), 61-62. 
European origin. In 1914, a boatload of Sikhs attempting to immigrate into Canada via Vancouver was turned back. ${ }^{21}$ They were only one of many groups historically excluded. Chinese laborers were imported into Canada to build the Canadian National Railway, but once it was completed most of them were deported, and those few who were permitted to stay were not allowed to sponsor their wives and children into the country until well after World War Il. Canada did not open its doors to refugee Jews during the Nazi period. ${ }^{22}$ Both non-citizen and citizen ethnic Japanese were subjected to mass internment during the Second World War. ${ }^{23}$ After the war, about 4,000 citizens of Japanese ethnic descent were deported to Japan. ${ }^{24}$ The Chinese Immigration Act passed in 1923 in order to stop Chinese immigration was revoked in $1947,{ }^{25}$ but the racial basis of Canada's immigration policy was not fully eliminated until 1967, when a non-racial point system based on wealth, occupation, education, and entrepreneurial abilities was adopted for independent immigrants not sponsored by family members already in Canada. By 1986 about five percent of the residents of Canada were of nonEuropean, nonindigenous origin. ${ }^{26}$

The result of the new criteria of immigration introduced in Canada in 1967 is that most non-white immigrants are quite well educated and some groups, such as Koreans, Japanese and Indo-Pakistanis have higher per capita incomes than some Euro-Canadian ethnic groups such as Ukrainians, Portuguese, and Greeks. ${ }^{27}$ These non-white immigrants, known as "visible minorities," certainly do not conform to the previous image of Canada as a whites-only country (indigenous peoples having been regarded for decades as anomalous and irrelevant, if not inexorably doomed to extinction). Yet their aspirations and their lifestyles fit very closely with Canada's community of character. In most cases, the immigrants had fully adopted so-called "Canadian" values such as hard work, capital accumulation, and investment in home and family before they arrived in the country. They are also eager to adopt the Canadian social values of individual freedom of choice in

21. The Canadian Encyclopedia (Edmonton: Hurtig, 1985), 2:948.

22. Irving Abella and Harold Troper, None is Too Many: Canada and the Jews of Europe 19331948 (Toronto: Lester and Orpen Dennys, 1983).

23. Ken Adachi, The Enemy that Never Was (Toronto: McClelland and Stewart, 1976).

24. Ellen Baar, "Issei, Nisei, and Sansei," in Modernization and the Canadian State, eds. Daniel Glenday, Hubert Guindon and Allan Turowetz (Toronto: Macmillan, 1978), 348.

25. E. B. Wickberg, "Chinese," in The Canadian Encyclopedia (Edmonton: Hurtig, 1985), $1: 336$.

26. Calculated from Statistics Canada, The Nation: Ethnicity, Immigration and Citizenship (Canada Census, 1986) (Ottawa: Minister of Supply and Services Canada, 1989), 1-1, 114. European origins calculated by adding single and mixed origins.

27. Conrad Winn, "The Socio-Economic Attainment of Visible Minorities: Facts and Policy Implications," in Social Inequality in Canada: Patterns, Problems, Policies, eds. James Curtis, Edward Grabb, Neil Guppy, and Sid Gilbert (Scarborough: Prentice-Hall, 1988), 197. Data based on 1981 census. 
occupation, religion, and politics. Aside from skin color, they are distinguished from Euro-Canadians only by language retention by first-generation immigrants and by some symbolic aspects of culture such as religion and ritual behavior.

Nevertheless there has been a great deal of public hostility in Canada to the new non-white immigrants. During the 1970s, physical attacks on Asian immigrants were frequently reported; in Toronto, a Tanzanian was permanently crippled when he was pushed onto the subway rails. ${ }^{28}$ In the early 1980s, a major television news program broadcast an inflammatory report on how Chinese foreign students were taking up an inordinate number of places in the University of Toronto medical school; further investigation revealed that all of the people filmed were Canadian citizens of Chinese ethnic descent. In 1989-1990, public ire was aroused by a proposal that Sikhs in the Royal Canadian Mounted Police should be permitted to wear turbans. Many Canadians argued that to permit turbans would attack the prized tradition of the red Mountie jacket and broad-brimmed hat, and a petition of over 125,000 signatures opposing the change was presented to Parliament. Racist pins and calendars were produced in the Canadian West, including one calendar featuring a Sikh Mountie with the words "Sgt. Kamell Dung" written on it. ${ }^{29}$ The Prime Minister's statement that such objections resembled the behavior of the Ku Klux Klan annoyed many Canadians who defended "tradition" while asserting that they were not bigots. ${ }^{30}$

That Canada's official non-racially based immigration policy arouses so much hostility and opposition is not surprising. For many Canadians of European extraction, community of character is possibly only among people who share the same "racial" characteristics, if not as well the same (Christian) religion. If culture is an absolute social value, then those who kept Canada closed to non-European and non-Christian immigrants for so long acted ethically. Those who pressured for Canada to open its doors undermined its culture and were unethical. They should have recognized that immigration threatened Canada's basic social values, its very culture as a society of descendants of British and Northern European Christian immigrants. The introduction of liberal, non-racist social values into Canadian public policy in the 1960s destroyed this previous cultural unity.

Cultural absolutism is the antithesis of human rights. Positing culture as the highest social good, it permits, among many other human rights violations, the exclusion of outsiders from the pure and inviolable community. This contradiction cannot be resolved by making the false claim that all

28. "Racial Attacks Concern Toronto," Canadian News Facts 11 (19 Jan. 1977): 1699.

29. "Prairie Backlash: Anti-minority Campaigns Cause Heated Debate," Maclean's, 19 March 1990, 18-19.

30. E.g., three out of five letters on this subject in The Spectator (Hamilton, Ontario), 28 March 1990. 
societies' systems of social justice are systems of human rights, even when they violate such basic tenets of human rights as the principle of nondiscrimination. The belief that all systems of social justice are equally good reflects both Western romanticism of primitive societies, and a collective social amnesia regarding the nefarious effects of romantic communitarianism in recent Western history.

\section{RELATIVISM, PRIMITIVISM, AND ROMANTICISM}

In traditional societies, principles of social justice are based not on equal human rights but on unequal social statuses and on the intermixture of privilege and responsibility. Cultural absolutists refer to the existence of such traditional societies to argue against any presumed universality of human rights. Often anthropologically anachronistic pictures are presented of premodern societies, taking no account whatsoever of changes that might have occurred. Pictures constructed by anthropologists of how societies might have behaved "before the white man came" are presented as accurate descriptions of how those societies still behave, decades if not centuries later. Yet the great anthropologist Claude Levi-Strauss actually had to persuade the remnants of a tribe that he had set out to study to return to the bush with him, as they were just about to collectively join a Western settlement. Levi-Strauss was obliged to persuade his primitive community to stay primitive; his research plans were upset by the conscious decision his objects of study had taken to modernize. ${ }^{31}$ The use of anachronistic pictures of "native" societies to illustrate so-called cultural principles "airbrushes out" history. ${ }^{32}$

Westerners often prefer that native societies be unchanging because of their belief that natives are their cultural ancestors. "Natives" represent a pure, idealized state of harmony and peace to which, someday, Westerners might return. In these societies, human rights are unnecessary because conflict is unknown. The anxieties of modern civilization are not inevitable; they are a contingent accompaniment to modernity that Westerners may be able to eliminate if they can find the true path back to communal living. Yet the ethnographic studies on which cultural absolutists rely are not neutral, objective pictures. Contemporary anthropologists sympathetic to the cultures they study as are likely to overdraw their pictures as were their earlier, arrogantly colonialist forebears. Anthropological conclusions both about the

31. Marianna Torgovnick, Cone Primitive: Savage Intellects, Modern Lives (Chicago: University of Chicago Press, 1990), 181.

32. James Clifford, The Predicament of Culture: Twentieth Century Ethnography, Literature and Art (Cambridge, Mass.: Harvard University Press, 1988), 202. 
substance of cultural values and about the integrative, unchanging nature of cultural norms are drawn from highly questionable data that reflect both the arrogance and the romanticism of Western observers.

Many of these pictures of indigenous cultures are a right-side up version of what Edward Said has called Orientalism. By Orientalism, Said refers to a pejorative view of the "Orient," or more particularly, of the Middle Eastern Islamic world. In the Orientalist perspective, the presentation of Islamic societies as unchanging, holistic entities is used pejoratively to suggest their incapacity to adapt to ethically superior modern ways.

Islam is a unitary phenomenon, unlike any other [Western] religion or civilization. . . . [It is] monolithic, scornful of ordinary human experience, gross, reductive, unchanging. ... [For Orientalists] there are still such things as an Islamic society, an Arab mind, an Oriental psyche. . . "Arabs" are presented in the imagery of static, almost ideal types, and neither as creatures with a potential in the process of being realized nor as history being made. ${ }^{33}$

Cultural absolutists often present the inverse of Orientalism, not a pejorative picture of the societies they discuss but a complimentary, romanticized picture. In so doing, however, they use the same idiom of unchanging societies unaffected by human history. And they often attribute these characteristics to entire geographical regions or religions, as if a culture can be completely identified by its location or its religious beliefs. Said comments on this tendency to attribute cultural characteristics to entire regions of the world.

"[T]he Orient" is itself a constituted entity. . . . [T]he notion that there are geographical spaces with indigenous, radically "different" inhabitants who can be defined on the basis of some religion, culture, or racial essence proper to that geographical space is . . . a highly debatable idea. ${ }^{34}$

In academic discourse we no longer use racial stereotypes, yet in human rights debates commentators persist in stereotyping all the inhabitants of non-Western geographical regions with the religio-cultural beliefs that these commentators believe must define the non-Westerners' lives and dominate their thoughts.

Many Westerners-explorers, anthropologists, culturally-sensitive analysts of human rights-impose on the "traditional" societies they encounter their own desires to find a romantic, rustic original state in which social harmony prevails. This romanticization of "backward" or "primitive" cultures is a right-side-up Orientalism, not criticizing but idealizing. The ab-

33. Edward W. Said, Orientalism (New York: Vintage Books, 1978), extracts from 296, 299, 301,321 . Emphasis in original.

34. Ibid., 322. 
solutist denial of universal human rights revels in the romantic mysticism of primitive society.

The relativist [absolutist] ... often defines the interests of a people in mystical or aggregative terms that ignore or belittle individual preferences. Such mystical definitions may be articulated in the form of axiomatic "true" interests of peoples, as opposed to real or expressed interests. ${ }^{35}$

Cultural absolutism then is a spinoff of Western primitivism, the simultaneous idealization and denigration of the "primitive" that has characterized Western culture since the mid-nineteenth century. Primitivism as an ideal began with the early European explorations to such remote places as "darkest Africa" where, it was thought, man was his true natural self, at one with nature. "Primitives are mystics, in tune with nature, part of its harmonies. Primitives are free." ${ }^{\prime 36}$ Contemporary idealization of third world cultures is a new version of that same trend.

Denial of the individuality of members of these societies merges them into one amorphous whole, in which cultures are at risk of being destroyed (for example by introducing new norms of human rights) but actual people are not. When the people who comprise these romanticized cultures are considered not real individuals with their own needs, wants, and desires but rather living anthropological exhibits, then their human rights can go unheeded. The primitive by definition is natural and cannot have the socially constructed desires for human rights that Westerners have as refined, alienated social beings. The primitive is not capable of abstract thought, of stepping out of her environs to consider the nature of social life or the ethics of her group. Thus to introduce the ideal of human rights even into verbal discourse with a primitive is to be an imperialist, to set off a process of social change that may well wreck the indigenous social order.

That Westerners themselves might once have been primitives whose societies underwent centuries of social change is of no consequence here. Those primitive societies that still exist are taken to be our psychological ancestors. We need their existence, even when their social organization may well be exploitative of, or cruel to, many of their members so that we can have a mythic past of purity. Their organic wholeness, their oneness with nature, their repression of individual choice appeals to a Western desire for an imagined simpler world. Primitives are communitarians par excellence, unpolluted by ideas of individualism or competition. In their societies, no one questions the rules; everyone, even the lowliest, lives in harmony with others and with authority. Thus the appeal of the primitive not only to left romantics, but also to right traditionalists.

35. Teson, note 10 above, 882 .

36. Torgovnick, note 31 above, 8 . 


\section{COMMUNITARIAN VERSUS INDIVIDUALIST PERSPECTIVES ON SOCIETY}

The cultural absolutist critics of universal human rights look for a world that no longer exists, if it ever did: a world of community, of integrative membership of the individual in the group, and of a wholeness and unity with nature. Absolutists' defense of indigenous cultures against universalized human rights is to a large extent a consequence of their concern that human rights will encourage the emergence of an individualized, atomistic, and competitive social world. Absolutists idealize the third world community, which exemplifies for Western culture the primitive arcadia we have lost, even as the third world displays some of the worst human rights abuses of early modernization.

In the absolutist perspective, the preservation of the corporate entity of the community will do more to preserve human rights than introduction of the principle that the individual may make claims against society and the state. This corporate community, a product of over two hundred years of romantic reaction to the individualizing and liberating tendencies of modern capitalist society, is completely unproblematic. In its romantic rendering, internal inequities, power relationships, and brutalities disappear in a foggy haze of mythological collectivity. The "traditional" way of life beckons to our anxious citified psyches, reminding us all of the pristine collective origins from which we spring.

Individuals living in primitive, pre-capitalist communitarian societies are not permitted to change or to think about what they would like from life. Certainly, they are not permitted to deny our dream of Utopia by adopting Western artifacts or ideas. The Tasaday of the Philippines, for example, were accused by anthropologists of being fake primitives when they started to wear blue jeans and eat cheese crackers. ${ }^{37}$ In a similar vein, the contemporary primitives of third world societies are not permitted to be attracted to, to adopt or advocate, individualist ideals of personal autonomy or human rights. Those individuals from the third world who do express such ideas are quickly dismissed as "Westernized;" that is, as unauthentic, offending our view of the psychological role they play for us. "[I]t is critical to realize that the Western-based notions of human rights, to the extent that they are articulated by third world political elites, reflect these elites' 'Westernization.' "'38 While we value intellectual independence in our own tradition we refuse it to intellectuals in others; they are supposed to be conservative exemplars, not radical challengers, of their own traditional values.

The anti-individualist trend of the traditionalist nostalgia for community

37. Ibid., 259 n.58.

38. Pollis and Schwab, note 4 above, 12. 
harbors a romantic tendency to ignore or disguise the many repressive and harmful effects (from a human rights perspective) of communitarian societies. This nostalgic discourse pits the allegedly alienated individualism of late twentieth century capitalist society against the supposed security and personal rootedness of life in the collectivity. It ignores the liberating aspects of individualism and forgets that collectivities can be highly oppressive social entities.

Communitarians and individualists have radically different perspectives on the value of social life in the two types of societies. Those who favor communitarian society value the fact that within it one's ties are prescribed by one's relations to family and kin. Within that network of ties, sex and age roles are carefully defined and androgynous life choices (stepping over the boundaries of male and female roles) unheard of. Deviance is universally abhorred and punished. Communitarians abhor the fact that in individualist society, by contrast, androgyny is permitted and "lifestyle" choices that offend the natural order of kinship and family are tolerated. In the communitarian perspective, individualists who reject family ties have no other ones and consequently feel anomie-a disconnection from society-and normlessness.

In the communitarian perspective, socially-prescribed roles, freely fulfilled, are assumed to result in rootedness in society. Such rootedness cannot exist for the presumably alienated Western individual, who experiences the confusion of having to make autonomous choices about how to live his or her life. Individualist society exhibits a free-for-all tolerance of disruptive, anomic deviance which carries with it a disregard for the actual consequences of deviant acts. The individualist adrift in a sea of normlessness, casting about for new rules to regulate his life, is confused and alienated from society, while his communitarian counterpart is firmly rooted in his social group.

For communitarians, social stratification is a sensible allocation of roles. Although honor is based on rank, there is no shame attached to those who are slotted into lesser positions as long as they fulfil their prescribed tasks with diligence. Caste distinctions are acceptable and all castes, including slaves, cooperate for the greater good of the whole community. Thus there is an underlying equality of respect. In individualist society, by contrast, those inherently deserving of respect, such as the aged or the priests and lawmakers, are frequently denied it. Ascribed caste distinctions give way to unpredictable class distinctions arising from unregulated competition for wealth and prestige; the "fittest" dominate by ignoring their obligations to others. The social whole breaks down into an anarchical system, in which neither respect nor economic security can be guaranteed even to those who dutifully fulfil their obligations to family, kin and society.

Thus individualism challenges the routine and valued orderliness of communitarian society. Upstarts abound, people abandon their social roles, 
honor disappears. Quiet communitarian life gives way to normative and social chaos.

In the communitarian view, the underlying glue that holds society together is its culture. The culture tends to be static and orderly; very little change is foreseen. One's primary identity comes from one's family or kin, then from larger social structures such as one's unchanging group, defined as ethnic, religious, or national. There is no social conflict within this group; rather, everyone accepts its rules and roles. Implicitly, the communitarian view denigrates social deviance and the stepping outside of social roles that, for example, women's liberation and the black civil rights movement have permitted in the Western world. Instead, it is assumed that contentedness comes from fitting into the group. It is also assumed that members of such closed corporate groups can and do live together in mutual tolerance when not rent by the selfish claims of individualistic deviants.

The individualist view of the antithesis between communitarian and individualist society is quite different. It stresses the repressive, discriminatory features of the ideologized communitarian society. In its view, prescribed family and kin ties are repressive or, indeed, demeaning and violent, as in the case of patriarchal violence against women and children. The social individual, therefore, ought to be free to choose other social networks that may be more important to her than family or kin. In individualist society no one is locked into traditional, prescribed social roles: sex roles can be ignored and deviance from traditional ways of life is permitted.

Individualists perceive the belongingness of closed social groups to encourage racial or ethnic exclusivism, while a more open society encourages real tolerance of others whatever their racial, ethnic or other ascriptive affiliations. In individualist society, a person must form an autonomous sense of herself, which may or may not result in a conscious decision to obey the social norms prescribed by tradition. Individual achievement is celebrated, while categorization of people on the basis of nonautonomous traits having nothing to do with personal achievement is viewed as degrading.

In the individualist world, respect must be earned; one is not entitled to it merely by virtue of one's rank. Shame is just as much a characteristic of communitarian society as honor; to be respected because one fills one's lowly position without complaint is in fact to suffer from permanent dishonor. No hierarchies of status exist in the individualist world; indeed, there are no inherent statuses at all. The unhealthy social regulation of traditional society is replaced by a healthy competition in which the best rise to the top solely on the basis of their own efforts. Individualists see social uniformity of communitarian society as repressive. Thus in the individualist view, change permits diversity, the rise and fall of individuals as their capacities dictate, the choice and evolution of new communities and new ways of living, the end of all inherent status rankings. A society in flux is a society that is progressing. 
These schematized ideal types do not represent real societies. Individualist societies contain many communitarian features. And as communitarian societies change, they approach the individualist model in culture as well as in politics and economics. Both in practice and in theory, we need to reconcile the communitarian and the individualist account of society. The communitarian account is too critical of the breakdown of community and tends to refer back to romanticized models, while the individualist account is too uncritical of the costs of individualism. The polarization of these two accounts of ideal society prevents discussion of the human rights abuses that exist in both and that an uncritical defense of "culture," whether closed and traditional or open and competitive, can generate.

\section{CULTURAL ABSOLUTISM AND THE CONSERVATIVE REACTION}

The absolutist critique trumpets the right to community over individual human rights, but only for people in other societies for whom critical and abstract thought is unauthentic. Thus in the culturally differentiated third world the individual loses her capacity to claim fulfillment of her human rights from the state or society; she renounces her human rights for the greater good of the collectivity. This renunciation is costless to her because her identity is merged with that of the group, so that human rights on an individual basis would seem not only irrelevant, but laughable. She is merged with her family and society in an organic oneness that fulfills both her creative and her social needs. And of course, since in this rendering she either does not live in a state or class society or is untouched by the state's or the ruling class' political and economic interests, she is entirely without need for the classic civil and political rights.

In the communitarian view of individualist rights-protective society, autonomy is seen as alienation. Pollis, for example, refers to the Western view of man as an "isolated, autonomous" creature. ${ }^{39}$ Autonomy, however, does not necessarily mean alienation from the community. Autonomy does mean that the individual makes decisions for herself and may well refuse socially prescribed roles in favor of other roles that seem preferable. The autonomous individual in Western society is frequently one who is connected to the community through freely chosen associations and friendships, as well as through continued family ties. Autonomously formed groups, subcultures, and neighborhoods abound in Western culture. The autonomous individual is not necessarily an alienated individual; she can rather be the

39. Adamantia Pollis, "Liberal, Socialist and Third World Perspectives on Human Rights," in Toward a Human Rights Framework, eds. Peter Schwab and Adamantia Pollis (New York: Praeger, 1982), 7. 
"public man [person]," actively involved in the community and participating in political decisions. ${ }^{40}$ The decline of publics into masses, or the transformation of independent citizens into manipulable robots, is not a necessary consequence of individualism.

This does not mean that the tension between individual and community does not need to be examined. The unbridled individualism and materialism that became characteristic of some sectors of the North American population in the 1970s and 1980s is an antisocial phenomenon. It is not accidental that the worst excesses of individualism are found in the United States, where economic human rights in particular carry very little weight. The culture of late twentieth century North America celebrates freely-chosen, individualistic lifestyles. But "lifestyles" can be a matter of choice only for those in an economic position to choose; for many if not most people, the substantive realities of economic insecurity preclude any capacity to choose a particular individualist style of living even in Western society.

While autonomy and choice free individuals from often abusive social constraints, competition results in a lack of responsibility for others. To base respect solely on what is earned, rather than to respect people merely because as human beings with thoughts, feelings, and souls they deserve respect, casts many onto the dungheap of capitalism. The ideology of achievement now permits societal disregard of those who have not achieved, or who cannot achieve, given the historic disabilities under which they labor. While communities thrive in many areas of North America, in other areas collective responsibility for social welfare has disappeared via white flight, tax revolt, and vulgar display of personal wealth.

Community is destroyed in modern societies where the individualist pursuit of wealth is the primary social value, and where the poor are systematically disregarded. The unbridled individualism typical of some sectors of the North American population is an indication that human rights are not being protected. Modern societies can be communities when the entire range of human rights-economic, social, and cultural as well as civil and political -is respected. In wealthy societies, such respect is certainly possible in practice, though it may be anathemic in principle to some sectors of such wealthy societies. Unbridled materialistic individualism is a strong argument for taking seriously the economic human rights upon which (in their rhetoric) socialist and third world countries have insisted in international debate. But it is not an argument for reducing autonomy, reimposing communitarian controls that limit individual choices, or eliminating the principle that individuals may make claims for their human rights on society and the state.

40. Robert N. Bellah, Richard Madsen, William M. Sullivan, Ann Swidler, and Steven M. Tipton, Habits of the Heart: Individualism and Commitment in American Life (New York: Harper and Row, 1985). 
Arguments for the absolute value of culture and for the importance of the petrified community over the individual result in political conservatism. The cultural absolutist approach to human rights has real political implications. If we are to accept that the community is more valuable than the individual and that culture must be preserved even at the expense of human rights, then we must discuss the question of priorities. When, as frequently happens, community norms, rules, or desires clash with individual rights, what will take precedence? The new communitarianism likes to pretend that these clashes do not occur, but they do. Communitarianism denies the existence of status degradation and oppression within all societies. The romanticization of "primitive" and "traditional" societies by relativist and third worldist critics exacerbates this trend.

The romantic communitarianism that some Western absolutists now propound as a legitimate argument against individual human rights also ignores the Western world's own history. In 1993, we are fewer than fifty years past the worst excesses of romantic communitarianism the world has ever seen. National Socialism glorified the collectivity over the individual, and built up a myth of a pre-Christian (non-Judaic) past in which; supposedly, a community of Aryan beings lived in close communion with nature. "In the beginning, the 'New Order' appeared as an instant solution to the quest of the masses for social dignity and a renewed community spirit. ${ }^{141}$ Nazism epitomized the underlying tendencies of Western culture to retreat from secularism, liberalism, and humanism into a romanticized past of order, stability, unchanging social roles, and complete social homogeneity.

The [romantic] German Weltanschauung ... [was] a total view of the (natural and social) world, fundamentally in conflict with the essentially humanist and rationalist thought typical of the rest of Western civilization. ... [The] personal "individualism" of the early Romantics very soon became transformed into an organic and nationalistic theory of community, each unique and self-sufficient, according to which ... the individual was "fated to merge with and become rooted in nature and the Volk" and would thus be "able to find his self-expression and his individuality." Moreover, individuality was ascribed no longer merely to persons, but to supra-personal forces, especially the nation or the state..$^{42}$

The revival of romantic communitarianism without adequate consideration of its potential for social corporatism, if not indeed renewed fascism, may well undermine the secularist, liberal, and humanitarian tradition of human rights that has provided some protections to deviants, outsiders, despised groups, and the oppressed over the past 200 years. The Nazis

41. Christa Kamenetsky, "Political Distortion of Philosophical Concepts: a Case HistoryNazism and the Romantic Movement," Metaphilosophy 3 (July 1972): 216.

42. Steven Lukes, Individualism (Oxford: Basil Blackwell, 1973), 19-21. His quotations are from G. L. Mosse, The Crisis of Cerman Ideology (London, 1966), 15. 
murdered Jews because they regarded them as modern, cosmopolitan, rootless slime..$^{43}$ They persecuted homosexuals because they denied their prescribed sex roles and their obligations to the German family, exhibiting, especially during the Weimar Republic, a free, autonomously chosen, and deviant lifestyle. ${ }^{44}$ They debated whether to preserve the Gypsies as ethnographic museum specimens of the noble savage or to kill them as unauthentic half-breeds, finally choosing the latter course..$^{45}$ In the Nazi mind, Jews and homosexuals epitomized selfish commercialism and individualism: Gypsies symbolized the worst impurities of contact between modernity and the primitive.

There appears to be a collective amnesia in the international human rights literature, an unstated agreement to no longer speak of fascism. We have forgotten that fascist ideology was rooted in a romantic notion of an abandoned communitarian past. We now prefer to dwell only on the "good" - peaceful, loving, accepting, mutually tolerant-aspects of community that are relevant to the current critiques of liberalism. Fascism, we seem to believe, can't happen again; no contemporary society would turn its community inward to the extent that the Nazis did.

Yet like the cultural underpinnings of most other societies, the cultural underpinnings of Western society do not all favor human rights. Human rights are an ideal emanating from certain strands of Western political philosophy, mainly liberalism and social democracy. These strands in their turn are in part occasioned by social changes in the modern capitalist period that generated secularism and humanism. The politically dominant cultural values of some Western countries may possibly mesh with the values of human rights in the 1990s, after forty-five years of pro-human rights propaganda and some real progress in law and practice. But even in the West, the values of human rights are tenuous and fragile. A far stronger case can be made that human rights are not the dominant Western cultural tradition than that they are. The Western philosophical and cultural traditions of social justice include not only liberalism, but also communism, corporatism, racism, and fascism.

The absolutist perspective meshes culture with tradition and with the past. It ignores the existence in the third world of disparate political regime types and the repressive philosophies that many espouse. But cultures in the twentieth century are very much determined by the capacities of political elites to influence values through the educational system, the mass media,

43. On Jews as slime, see Zygmunt Bauman, Modernity and the Holocaust (Ithaca, N.Y.: Cornell University Press, 1989), 39.

44. Richard Plant, The Pink Triangle: The Nazi War Against Homosexuals (New York: Henry Holt, 1986).

45. Donald Kenrick and Grattan Puxon, The Destiny of Europe's Gypsies (London: Heinemann, 1972), 93. 
and political incorporation. We are not our ancestors, either our mythic, pre-historic ancestors or our immediate ones. Every individual and every cultural group is now influenced by a central state apparatus adhering to one or another political ideology. To espouse cultural absolutism as if these political regimes do not exist is, in effect, to espouse political relativism and to argue that all regime types possess ethically equal "cultures" of human rights.

Romantic communitarianism now buttresses many of the criticisms of liberal individualism made by political regimes on both the left and the right. On the left, the discredited communist criticism of human rights as bourgeois and individualist was picked up in the 1970 s by third world spokespersons who still sometimes argue that their traditional communities have no room for individual claims against society or the state. On the right, the 1980s witnessed the spectacle of President Ronald Reagan of the United States extolling the virtues of traditional family life. Although his own life was one of freewheeling disregard for his children, ${ }^{46}$ he managed to indict liberalism as the major social force behind the American destruction of the family, ignoring how his own public policy measures contributed to that destruction. ${ }^{47}$

Liberalism in North America is overly individualistic. Some aspects of community have disappeared and some types of community, especially a community of whites and blacks, never existed. But these problems cannot be rectified by recourse to the myth of a golden arcadian past. Romanticizing non-Western societies as embodiments of the values that we have lost, or never had, does not solve our problems; it merely obscures theirs. ${ }^{48}$

Reliance on myths of communal living avoids discussion of serious ethical questions of how to ensure justice in the contemporary world. That much of the world was recently subjected to Western imperialism does not mean that it is now exempt from international ethical debate. Those who work for change within their own societies, and those who suffer both modern state-generated brutality and traditional rights abuses, are done a disservice by some Westerners' willingness to dismiss such suffering as culturally authentic, thus impervious to criticism from other cultural (philosophical, political) traditions.

Serious critical analysis of the human rights abuses that exist in nonWestern parts of the world does not necessarily imply imperialist policy recommendations. To criticize another society or political system because

46. Joan Didion, "Life at Court," New York Review of Books 36, no.20 (21 Dec. 1989): 3 passim.

47. On how public policy neglects the family in the United States, see Syivia Ann Hewlett, $A$ Lesser Life: the Myth of Women's Liberation in America (New York: Warner Books, 1986).

48. On how we never had some of these values, see Peter Laslett, The World We Have LostFurther Explored, 3rd ed. (London: Methuen, 1983). 
human rights abuses are intrinsic to its practices is not to advocate that one's own society should therefore take it over and rearrange matters. Contemporary human rights advocates are not the equivalent of nineteenth-century Christian missionaries; that their principles are sometimes coopted by selfserving political rhetoric does not mean that they are the de facto agents of their governments. Nor does ethical criticism of a society, whether one's own or others', imply that one regards all of its culture as unworthy. Many human rights-abusive practices that do exist are not intrinsic to the culture; rather they are consequences of economic or political interest.

Many critics of universal human rights from less-developed societies want to preserve their social values and are afraid that human rights will undermine them. But many aspects of culture, such as kinship patterns, art, or ritual, have nothing to do with human rights and can safely be preserved, even enhanced, when other rights-abusive practices are corrected. These include many aspects of public morality. The existence or abolition of polygynous marriage, for example, is not an international human rights issue, despite feminist objections to it in the West. Nor is the proper degree of respect one should show to one's elders, or the proper norms of generosity and hospitality. The apparent Western overemphasis on work at the expense of family is a cultural practice that third world societies can avoid without violating human rights. Many other such matters, such as whether criminal punishment should be by restitution or imprisonment, or whether homosexuals should have the right to ordination, can be resolved without violating international human rights norms.

Cultural absolutism forgives cruelty on the grounds that acting in accordance with the customs of one's own group is a universal moral principle. The actual values of various groups are brought to our attention when they seem to be universally "good," as in Renteln's highlighting of tendencies to limit retribution in small-scale societies, even though principled universality is rejected and only additive universality is accepted. But when the principles of such groups would seem to be "bad," when they condone denial of food to the weak or denial of respect to those ritually impure, they are ignored. Thus can non-Western societies be romanticized. In our longing for the good, we overlook evil, and claim we are doing so in the name of nonimperialist relativism. Culture is the absolute value, and individual suffering is lost in its embrace.

Cultural absolutists are the real ethnocentrists. They not only argue that no one's sense of justice can transcend the boundaries of her own culture, they also argue that one ought not to transcend them. When dealing with the underdeveloped world, abstract discussion of norms of human rights that do not reflect one's cultural embeddedness is a form of cultural betrayal. Nevertheless, the West is expected to adhere to such abstract notions when in contact with the rest of the world. It is expected to compensate for its past colonial depredations, act in a non-racist manner both in its international 
and its domestic politics, and respect others' cultures. This is a double standard. Cultural absolutists applaud ethnocentrism in underdeveloped societies, yet they expect the West to behave in ways that respect human rights and thereby do not adhere to its own cultural norms. And they consider the standards of human rights to which some Westerners and some thinkers and activists from the third world want their own society to adhere to be cultural impositions or imperialism. This denies to citizens of the underdeveloped world the right to use their reason to consider transcendent ethical norms which, if implemented in their own societies, might well result in the betterment of their own lives. 